\title{
OTOMATISASI PENERIMAAN DAN PENGIRIMAN PESAN DENGAN SISTEM TERDISTRIBUSI UNTUK MENDUKUNG PENYEBARAN INFORMASI AKADEMIK
}

Wangsit Setyoadi, Hero Wintolo, Yuliani Indrianingsih Jurusan Teknik Informatika

Sekolah Tinggi Teknologi Adisutjipto Yogyakarta informatika@stta.ac.id

\begin{abstract}
Advances in technology are increasing rapidly, especially in the field of information and communication technology provides convenience in exchanging information. One widely used communication tool today is the mobile phones which have facilities sending messages or SMS (Short Message Service). With the mobile phone application development, application technology of short message or SMS widely used for more general purposes, one of which is in the academic field. To facilitate the exchange of academic information, including financial data, grades, and exam schedules, distributed systems into tools that are able to provide and process information dynamically.

To facilitate the exchange of academic information between the school and students, they invented a system that is distributed for the dissemination of academic information that can be accessed via SMS.

Academic information dissemination system based on short message or SMS can enhance the effectiveness of the dissemination of information between the school and students. With a system of information exchange is expected to be faster and more controlled because the cost for all messages can be recorded.
\end{abstract}

Keywords: Desemination, Message, Distribution System.

\begin{abstract}
ABSTRAK
Kemajuan teknologi yang semakin pesat terutama dalam bidang teknologi informasi dan komunikasi memberikan kemudahan dalam melakukan pertukaran informasi. Salah satu alat komunikasi yang banyak digunakan pada saat ini adalah telepon genggam yang mempunyai fasilitas pengiriman pesan atau SMS (Short Message Service). Dengan perkembangan aplikasi telepon genggam, teknologi aplikasi pesan pendek atau SMS banyak dimanfaatkan untuk keperluan yang lebih umum, salah satunya yaitu dalam bidang akademik. Untuk memudahkan pertukaran informasi akademik yang meliputi data keuangan, nilai, maupun jadwal ujian, sistem terdistribusi menjadi alat bantu yang mampu menyediakan dan mengolah informasi secara dinamis.

Untuk memudahkan pertukaran informasi akademik antara pihak sekolah dengan mahasiswa, dibuatlah suatu sistem yang terdistribusi untuk penyebaran informasi akademik yang dapat diakses melalui SMS.

Sistem penyebaran informasi akademik berbasis pesan singkat atau SMS dapat meningkatkan efektifitas penyebaran informasi antara pihak sekolah dengan mahasiswa. Dengan adanya sistem ini diharapkan pertukaran informasi akan lebih
\end{abstract}


cepat dan terkendali karena biaya yang dikeluarkan untuk pesan dapat tercatat semua.

\section{Kata Kunci : Sistem Terdistribusi, Otomatisasi, Penerimaan, Pengiriman pesan, Akademik.}

\section{Pendahuluan}

Kemajuan teknologi yang semakin pesat terutama dalam bidang teknologi informasi banyak memberikan kemudahan dalam melakukan pertukaran informasi. Tuntutan kebutuhan informasi yang semakin banyak, mendorong terbentuknya suatu model komunikasi yang mampu melayani berbagai kebutuhan tertentu. Komputer dan teknologi merupakan salah satu sarana yang digunakan untuk dapat mendapatkan informasi yang cepat dan tepat.

Salah satu alat komunikasi yang banyak digunakan pada saat ini adalah handphone, yang mempunyai fasilitas Short Message Service (SMS). Kelebihan dari SMS yaitu biaya yang lebih murah dari pada berbicara langsung melalui handphone, sehingga banyak digunakan oleh masyarakat untuk melakukan transfer data dalam ukuran kecil. Dengan perkembangan aplikasi handphone tersebut, teknologi aplikasi SMS banyak dimanfaatkan untuk keperluan yang lebih umum, salah satunya yaitu dalam bidang pendidikan.

Saat ini banyak institusi pendidikan yang menerapkan teknologi informasi dan komunikasi yang berkaitan dengan proses peningkatan mutu pelayanan. Dalam meningkatkan efisiensi mahasiswa dalam mengakses sitem informasi akademik, diperlukan suatu teknologi yang memungkinkan suatu sistem dapat diakses dimanapun berada. Kebutuhan sistem tersebut dapat dipenuhi dengan memberikan pelayanan terhadap mahasiswa melalui pesan singkat atau SMS.

Teknologi komputer yang semakin pesat banyak digunakan oleh institusi pendidikan untuk menunjang kegiatan akademis. Sejumlah sekolah memulainya dengan memberikan fasilitas komputer di setiap meja karyawan administrasinya agar pembuatan laporan semakin cepat. Beberapa diantaranya sudah melangkah lebih jauh, yaitu dengan membangun suatu sistem untuk mengotomatisasi beberapa prosedur kerja yang bersifat rutin dengan jumlah data yang besar, seperti data akademik. Dengan kebutuhan seperti itu, sistem terdistribusi menjadi alat bantu yang tidak hanya mampu menyediakan informasi, namun juga mampu untuk mengolah informasi yang dinamis. Kebutuhan informasi akademik tidak hanya bagi pihak sekolah, tapi juga pihak mahasiswa. Untuk mempermudah penyaluran informasi akademik berupa data keuangan, jadwal ujian, maupun nilai dari seorang mahasiswa dari pihak sekolah ke mahasiswa, maka dibangun sebuah aplikasi berbasis SMS, sehingga mahasiswa tidak harus datang ke sekolah untuk memperoleh informasi dalam bidang akademik.

\section{Pengertian Sistem Terdistribusi}

Sistem terdistribusi adalah suatu kesatuan dari elemen-elemen yang saling berinteraksi secara sistematis untuk mendistribusikan data, informasi, proses, objek, dan layanan dari dan kepada pengguna yang terkait di dalamnya (Sutedjo Budi,2006). 
Adapun infrastruktur utama dari aplikasi sistem terdistribusi, meliputi:

1. Jaringan komputer baik dalam skala lokal (LAN), metropolitan (MAN), skala luas (WAN), maupun skala global (Internet).

2. Beragam perangkat keras dan lunak, serta pengguna yang berada dan saling terkait dalam sistem jaringan yang membentuknya.

Penerapam sistem terdistribusi merupakan bentuk usaha untuk memanfaatkan secara optimal sistem jaringan komputer yang dibangun di dalam perusahaan. Sistem terdistribusi dibangun dengan tujuan:

1. Mengatasi bottleneck.

Tumpukan pekerjaan pada suatu terminal dapat didistribusikan ke terminal-terminal lain.

2. Mendukung layanan yang tersebar.

Misalnya layanan penjualan dengan menggunakan terminal-terminal yang tersebar di berbagai tempat.

3. Mendukung sistem kerja jarak jauh.

Misalnya sistem kerja small office home office yang memungkinkan karyawan untuk bekerja dari rumah sehingga tidak harus datang ke kantor.

4. Memudahkan kerja kelompok.

Dengan memudahkan sharing data dan tetap memungkinkan kerjasama walaupun letak anggota kelompok berjauhan.

Adapun beberapa jenis arsitektur sistem terdistribusi ialah sebagai berikut:

1. Client Server

Client menghubungi server untuk mendapatkan data, yang kemudian memformat dan menampilakan pada pengguna

2. Tightly Coupled (Clustured)

Mesin-mesin terintegrasi yang menjalankan proses yang sama secara bersamaan dengan membagi tugas ke dalam beberapa bagian yang dijalankan masing-masing mesin. Apabila proses telah selesai, hasil pengerjaan masing-masing mesin digabungkan menjadi satu.

3. Peer-to-Peer

Arsitektur dimana tidak ada mesin yang menyediakan layanan atau mengelola sumber daya jaringan sehingga segala tanggung jawab dibagikan diantara seluruh mesin. 


\section{Perancangan Infrastruktur Jaringan}

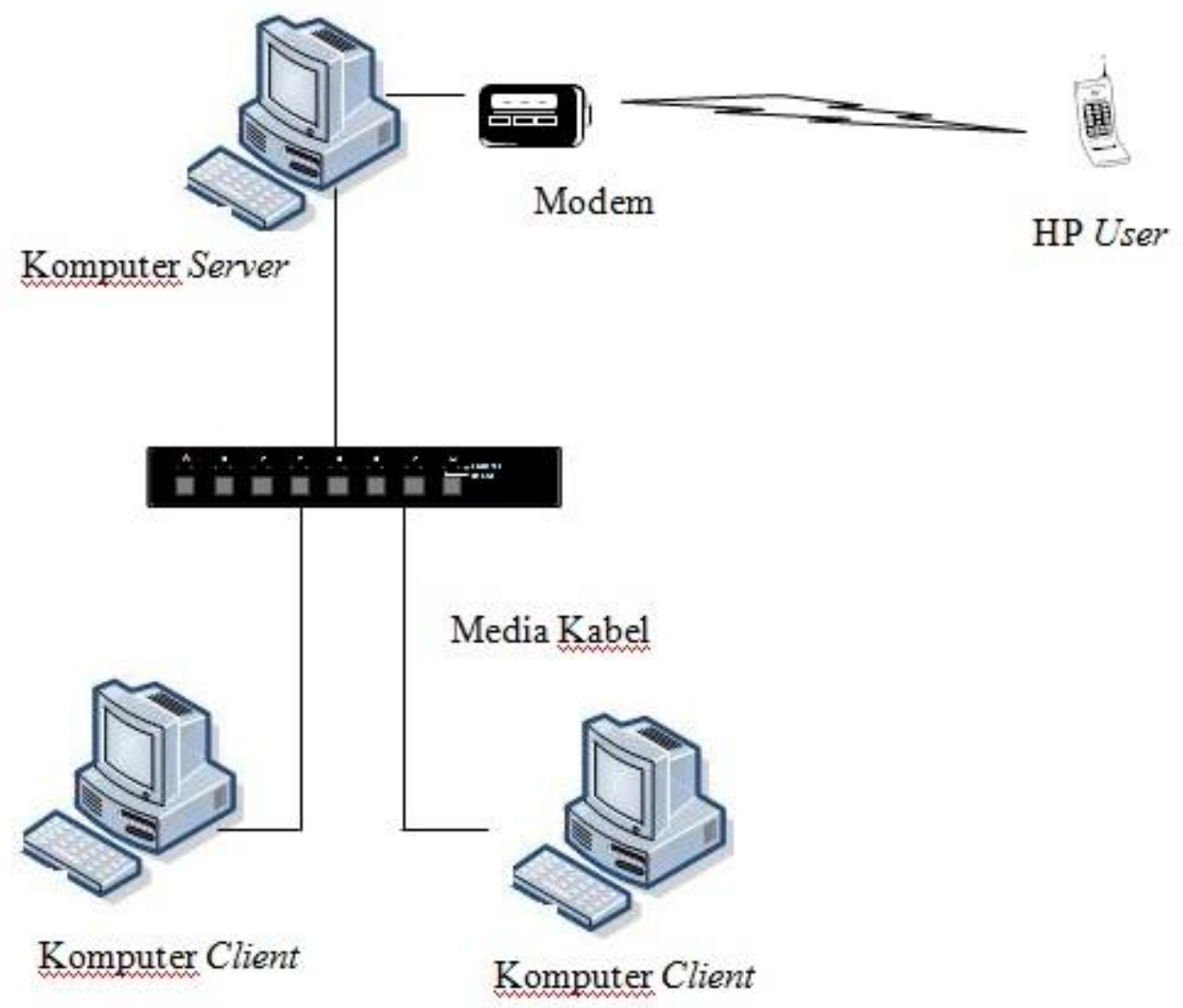

Gambar 1 Perancangan Jaringan

Pada dasarnya perancangan infrastruktur jaringan komputer tidak harus terpaku pada salah satu topologi jaringan saja, namun dapat disesuaikan menurut kondisi lapangan dan kebutuhan sistem. Perancangan jaringan pada penelitian ini menggunakan topologi star pada jaringan area lokal. Media transmisi jaringan menggunakan kabel UTP untuk menghubungkan antar komputer. Terdapat satu buah komputer yang dijadikan komputer server dan beberapa unit komputer yang dijadikan komputer client. Modem yang terhubung di komputer server difungsikan untuk melakukan pengiriman maupun penerimaan pesan dimana dalam modem sudah terdapat sim card kartu seluler, sehingga jalur komunikasi antara pengguna luar dan sistem jaringan melalui HP user dan modem. Struktur jaringan yang digunakan pada penelitian ini dapat dilihat pada gambar 1 .

Cara kerja aplikasi ini adalah pengguna harus mengirimkan pesan singkat (SMS) yang memenuhi format yang telah ditentukan. SMS yang dikirimkan pengguna akan diterima oleh aplikasi yang tedapat di komputer server. Jika format pesan sesuai dengan format yang telah ditentukan, maka aplikasi server akan meneruskan pesan ke aplikasi client sesuai dengan format pesan yang dikirim. Setelah aplikasi client menerima pesan yang dikirim oleh aplikasi server, 
maka pengguna aplikasi client dapat membalas pesan sesuai informasi yang diminta secara manual.

Adapun spesifikasi fungsi aplikasi server sebagai berikut:

1. Menerima pesan dari server.

2. Mengklasifikasikan pesan untuk dikirim ke aplikasi client.

3. Meneruskan pesan dari aplikasi client ke pengguna.

4. Melakukan record semua pesan yang keluar dan masuk.

5. Menyediakan koneksi untuk aplikasi client.

Adapun spesifikasi fungsi apliksi client sebagai berikut:

1. Menerima pesan dari aplikasi server.

2. Meng-inputkan balasan pesan sesuai dengan permintaan pengguna secara manual.

3. Melakukan koneksi ke aplikasi server.

\section{Flowchart System}

1. Flowchart aplikasi server untuk menerima pesan.

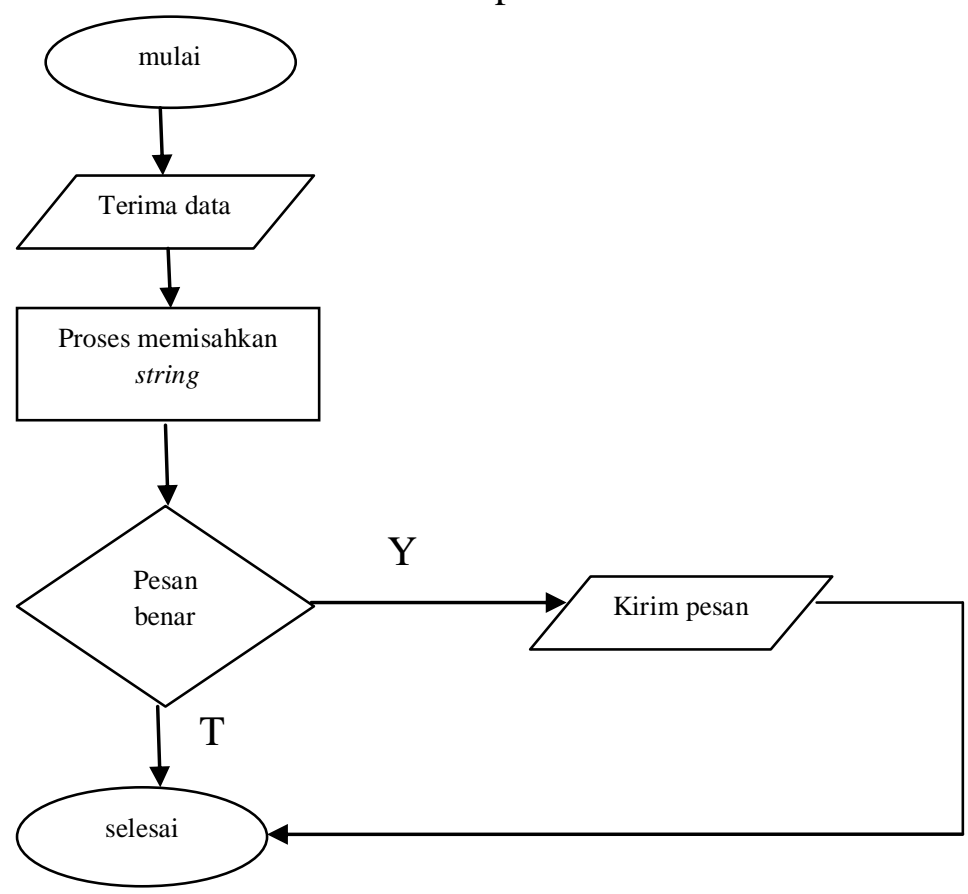

Gambar 2 Flowchart Aplikasi Server untuk Menerima Pesan.

Diagram alir atau flowchart adalah gambaran dalam bentuk diagram alir dari algoritma-algoritma dalam suatu program yang menyatakan arah alur program tersebut. Dalam diagram alir ini akan diketahui jalur dari progam dari awal sampai akhir. Diagram alir merupakan suatu model logika data yang dibuat untuk menggambarkan dari mana asal data dan tujuan data yang keluar sistem, proses apa yang menghasilkan data tersebut.

2. Flowchart aplikasi server untuk mengirim pesan.

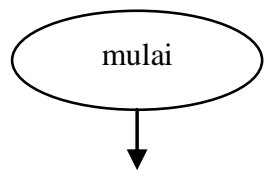




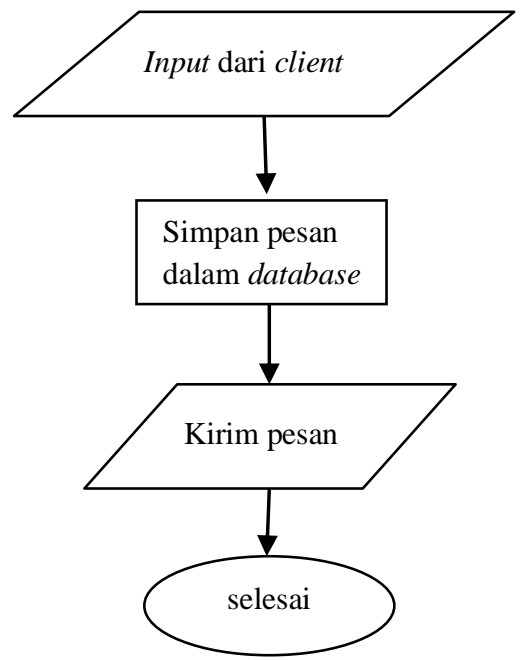

Gambar 3 Flowchart Aplikasi Server untuk Mengirim Pesan.

3. Flowchart untuk aplikasi client.

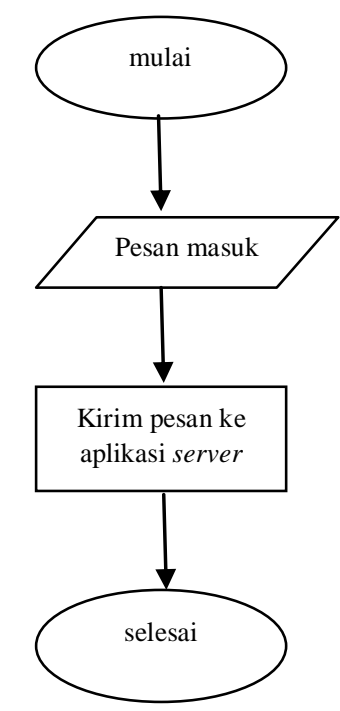

Gambar 4 Flowchart Aplikasi Client.

\section{Uji Coba dan Analisa}

Uji coba aplikasi ini dilakukan di STTA Yogyakarta. Hal ini dikarenakan karena STTA mempunyai sistem yang dapat mendukung jalannya aplikasi ini. Uji coba dilakukan menggunakan dua buah unit komputer yang telah terhubung dalam suatu jaringan dengan bentuk topologi seperti yang tergambar dalam konfigurasi jaringan. Dari beberapa unit komputer tersebut, satu unit komputer bertindak sebagai server dan yang lain bertindak sebagai client. Tabel 1 menggambarkan beberapa nama komputer dan alamat IP yang terdapat di STTA Yogyakarta yang dapat digunakan sebagai komputer yang bertindak sebagai client. 
Tabel 1 Nama komputer di STTA Yogyakarta

\begin{tabular}{|c|c|}
\hline Nama Komputer & Alamat IP \\
\hline Ketua & 200.168 .5 .1 \\
\hline PuketI & 200.168 .5 .2 \\
\hline PuketII & 200.168 .5 .2 \\
\hline PuketIII & 200.168 .5 .23 \\
\hline BPH & 200.168 .5 .3 \\
\hline SekjurTM & 200.168 .5 .5 \\
\hline Dosen & 200.168 .5 .6 \\
\hline KajurTI & 200.168 .5 .7 \\
\hline SekjurTI & 200.168 .5 .8 \\
\hline KajurTP & 200.168 .5 .9 \\
\hline SekjurTP & 200.168 .5 .10 \\
\hline KajurTF & 200.168 .5 .14 \\
\hline SekjurTF & 200.168 .5 .21 \\
\hline KajurTE & 200.168 .5 .12 \\
\hline SekjurTE & 200.168 .5 .11 \\
\hline LPMA & 200.168 .5 .28 \\
\hline LP3M & 200.168 .5 .18 \\
\hline Studio & 200.168 .5 .22 \\
\hline BAAK3 & 200.168 .5 .24 \\
\hline BAAK2 & 200.168 .5 .15 \\
\hline &
\end{tabular}

\section{Konfigurasi Jaringan}

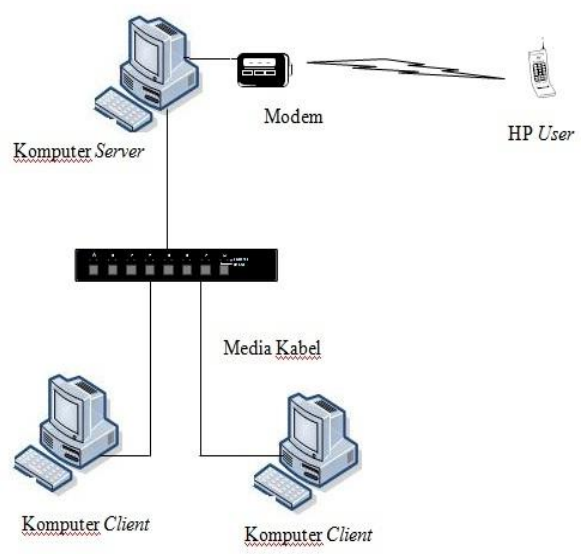

Gambar 5 Konfigurasi Jaringan

Untuk menjalankan aplikasi ini harus dilakukan konfigurasi jaringan terlebih dahulu. Peralatan yang dibutuhkan yaitu sebuah komputer yang digunakan sebagai server dan beberapa unit komputer yang digunakan sebagai client. Digunakan switch untuk menyatukan kabel-kabel yang terhubung antara komputer server dan beberapa komputer client. Modem dihubungkan dengan komputer server sebagai penerima pesan, dan sebuah handphone yang akan digunakan sebagai pengirim maupun penerima pesan. Gambaran dari konfigurasi jaringan yang digunakan pada aplikasi ini dapat dilihat pada gambar 5 .

\section{Uji Coba Aplikasi Server}


Untuk dapat menjalankan aplikasi server, pengguna harus mengisikan nomor port yang akan digunakan untuk melakukan koneksi ke modem dan mengisikan nomor port yang akan digunakan untuk koneksi ke aplikasi client. Semua client akan berada pada status offline, keadaan offline itu akan berubah menjadi online apabila aplikasi client tersebut melakukan koneksi ke aplikasi server. Dalam aplikasi server juga digunakan untuk menambah dan menghapus jumlah client. Semua pengguna aplikasi client terdaftar di aplikasi server. Daftar client berupa nama komputer, IP Addres dan status. Untuk uji coba aplikasi server ditunjukkan seperti pada gambar 6 .

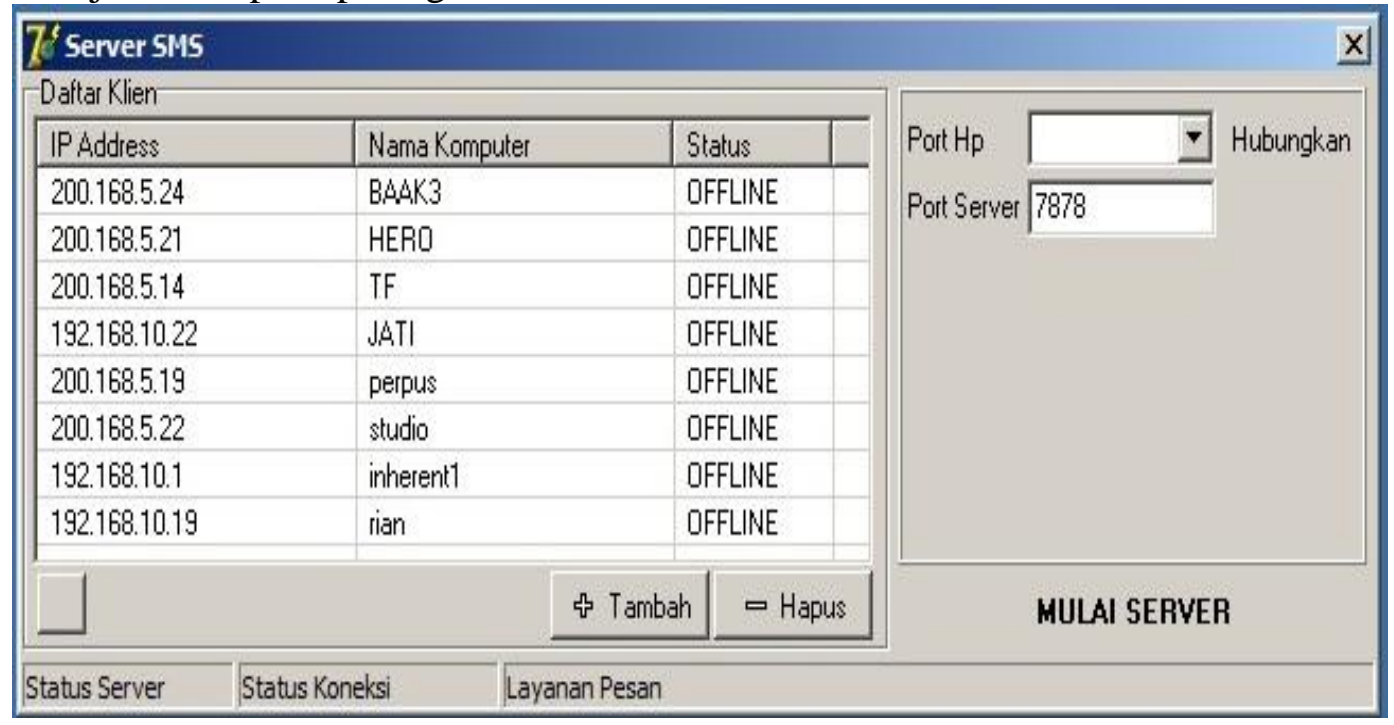

Gambar 6 Uji Aplikasi Server

\section{Uji Coba Aplikasi Client}

Data berupa IP Address dan nama pengguna pada aplikasi client harus terdaftar terlebih dahulu di aplikasi server. Untuk dapat menjalankan aplikasi client, pengguna harus mengisikan nomor IP dari aplikasi server dan mengisikan nomor port yang telah ditentukan oleh aplikasi server sebagai jalur komunikasi. Aplikasi client akan menampilkan pesan apabila terdapat pesan yang masuk ke aplikasi client tujuan, dan pengguna dapat membalas pesan tersebut langsung menggunakan aplikasi client. Aplikasi client tidak hanya dapat digunakan untuk membalas pesan, tapi juga dapat digunakan untuk mengirimkan pesan baru ke nomor tujuan yang diinginkan oleh pengguna. Semua pesan yang masuk di aplikasi client akan ditampilkan, yaitu berupa nama pengirim, isi pesan, dan waktu masuknya pesan. Aplikasi client dapat memutuskan koneksi dengan aplikasi server dengan menekan tombol diskonek yang tersedia pada aplikasi. Uji coba untuk aplikasi client dapat dilihat pada gambar 7 . 


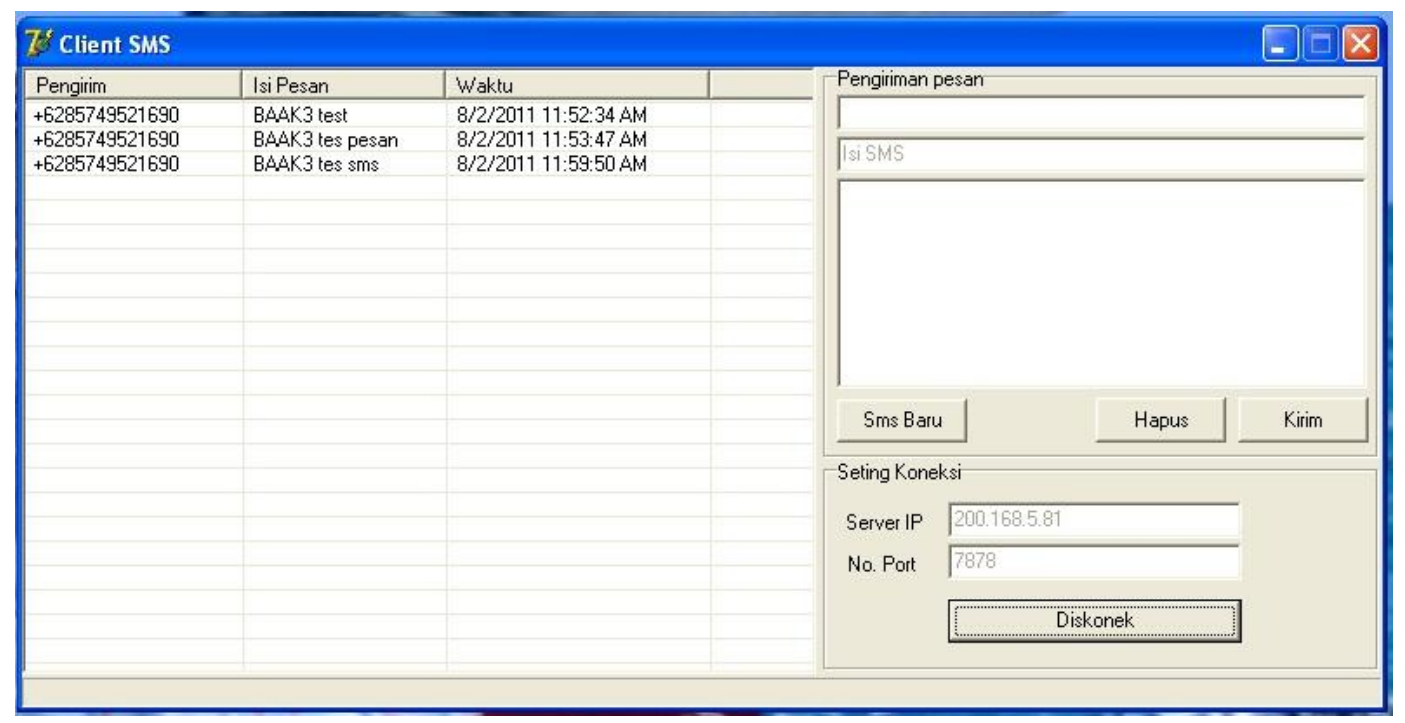

Gambar 7 Uji Aplikasi Client

\section{Uji Coba Penerimaan Pesan Oleh Client}

Dalam uji coba penerimaan pesan oleh client, aplikasi server dan aplikasi client harus terkoneksi terlebih dahulu, dengan menyamakan nomor port untuk kedua aplikasi tersebut sebagai jalur komunikasi dan aplikasi client harus mengisikan nomor IP dari komputer server. Setelah kedua aplikasi terkoneksi, maka pesan yang dikirimkan oleh seseorang yang ditujukan kepada aplikasi client dapat ditampilkan, sebelum pesan tersebut tampil di aplikasi client, pesan melewati aplikasi server dan disaring untuk menentukan ke aplikasi client mana pesan tersebut ditujukan. Pesan yang ditampilakan dalam apilkasi client berisi nomor dari pengirim pesan, isi pesan, dan waktu pesan tersebut masuk. Pesan yang dikirim ke client telah melewati server dengan membaca string pesan sebelum spasi yang menunjukkan tujuan client. Seperti ditunjukan pada gambar 8 bahwa SMS tersebut dikirimkan ke client yang bernama BAAK3, sedangkan string pesan setelah spasi merupakan isi dari pesan. Dalam uji coba ini digunakan beberapa buah komputer client yang dikirimi pesan yang berbeda, dan aplikasi client dapat menerima semua pesan yang dikirmkan. Hal ini digambarkan pada tabel 2. Gambar dari aplikasi client yang menerima pesan ditunjukkan seperti pada gambar 9.

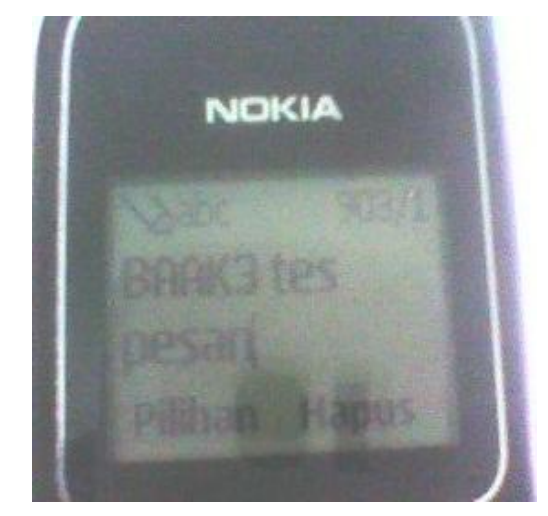

Gambar 8 Pesan yang Dikirim ke BAAK3 
Tabel 2 Uji Menerima Pesan

\begin{tabular}{|c|c|c|c|}
\hline No & Nama Komputer Client & Diterima & Tidak Diterima \\
\hline 1 & BAAK3 & V & - \\
\hline 2 & HERO & V & - \\
\hline 3 & TF & V & - \\
\hline 4 & inherent & V & - \\
\hline 5 & inherent7 & V & - \\
\hline
\end{tabular}

Dari tabel uji menerima pesan diatas, dapat diketahui bahwa komputer client yang telah dilakukan uji coba, yaitu BAAK3 dan lainnya berhasil menerima pesan yang dikirimkan oleh pengguna. Dari beberapa kali uji coba yang dilakukan di beberapa komputer client, semua pesan yang dikirnkan dapat diterima, dan tidak ada pesan yang gagal diterima oleh aplikasi client.

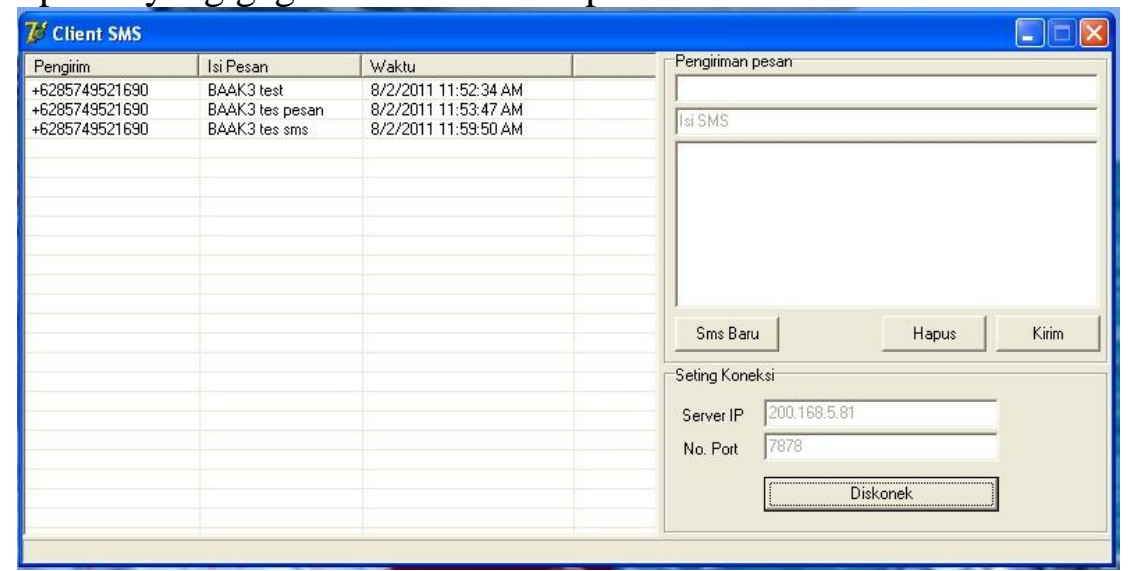

Gambar 9 Komputer Client BAAK3 Menerima Pesan

\section{Uji Mengirim Pesan}

Dalam uji mengirim pesan ini, dilakukan uji coba ke beberapa komputer yang terdapat di STTA Yogjakarta. Pesan yang dikirim oleh aplikasi client dapat berupa pesan baru maupun membalas pesan yang sudah masuk. Apabila ingin mengirim pesan baru, pengguna harus memasukkan nomor tujuan dari penerima pesan, sedangkan jika ingin membalas pesan, pengguna dapat mengambil nomor tujuan pesan dari pesan yang masuk. Gambar dari pesan yang dikirim oleh BAAK3 dan masuk ke handphone tujuan dapat dilihat pada gambar 10 dan 11 . Tabel 3 memuat data uji coba pengiriman pesan yang dikirimkan ke komputer BAAK3 dan lainnya. 


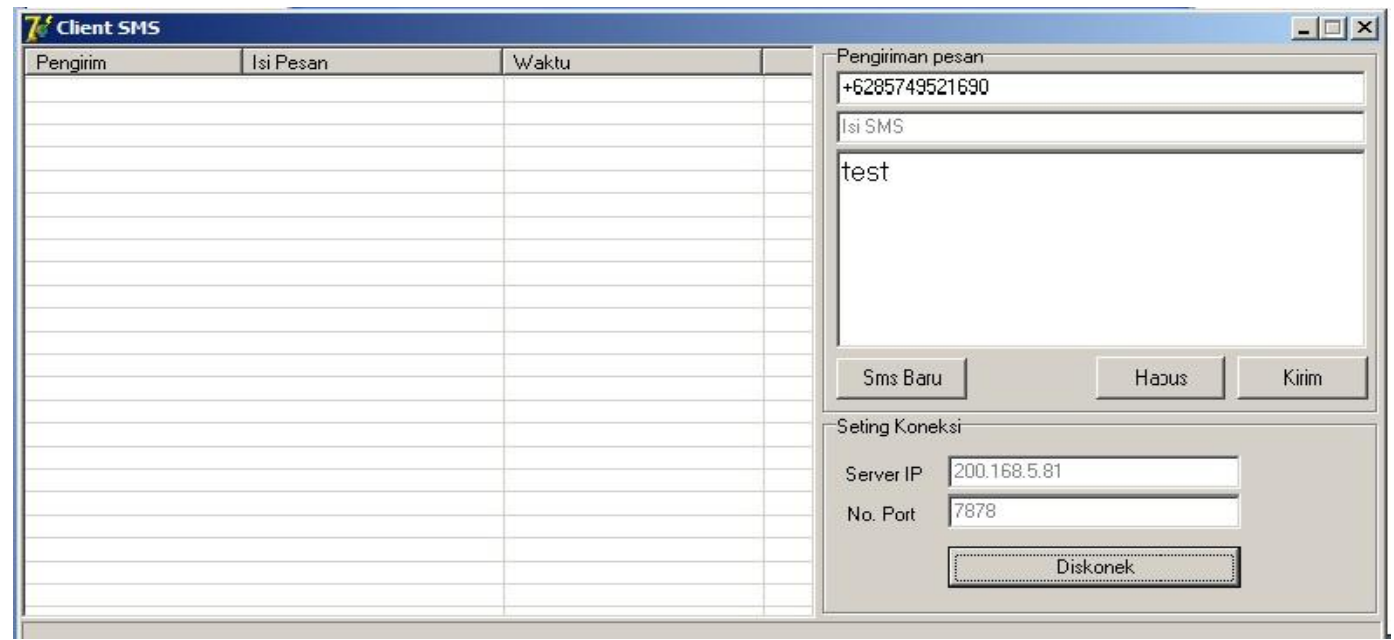

Gambar 10 Aplikasi Client Mengirim Pesan

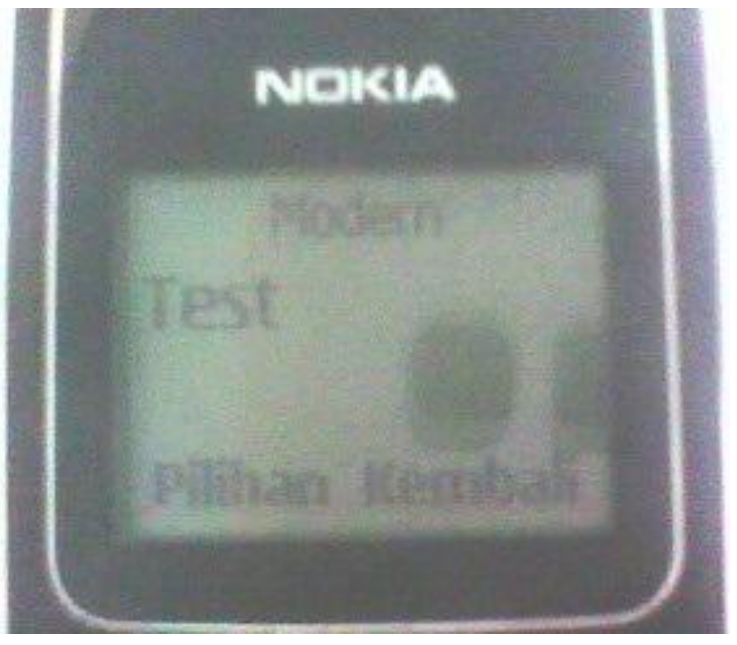

Gambar 11 SMS dari Aplikasi Client Masuk ke Handphone

Tabel 3 Uji Pengiriman Pesan

\begin{tabular}{|c|c|c|c|c|}
\hline No & Nama Komputer Client & No HP & Terkirim & $\begin{array}{c}\text { Tidak } \\
\text { Terkirim }\end{array}$ \\
\hline 1 & BAAK3 & +6285749521690 & V & \\
\hline 2 & BAAK3 & +6285747104906 & V & \\
\hline 3 & HERO & +6285749521690 & V & - \\
\hline 4 & HERO & +6285749521690 & V & \\
\hline 5 & Inherent7 & +6285749521690 & V & \\
\hline 6 & Inherent7 & +6285244470215 & V & \\
\hline
\end{tabular}

Dari tabel uji coba pengiriman pesan diatas dapat diketahui bahwa semua pesan yang dikirimkan oleh komputer client, dalam hal ini komputer BAAK3 dan yang lain berhasil mengirimkan pesan ke nomor tujuan. Nomor tujuan pengiriman pesan tidak terbatas pada satu buah nomor saja, tetapi bisa menggunakan nomor yang berbeda-beda.

\section{Uji Mengirim ke Banyak Nomor}


Dalam uji pengiriman sebuah pesan ke banyak nomor, dilakukan dengan memasukkan nama-nama yang telah tersimpan pada buku telepon. Gambaran dari pengiriman pesan ke banyak nomor dapat dilihat pada gambar 12 .

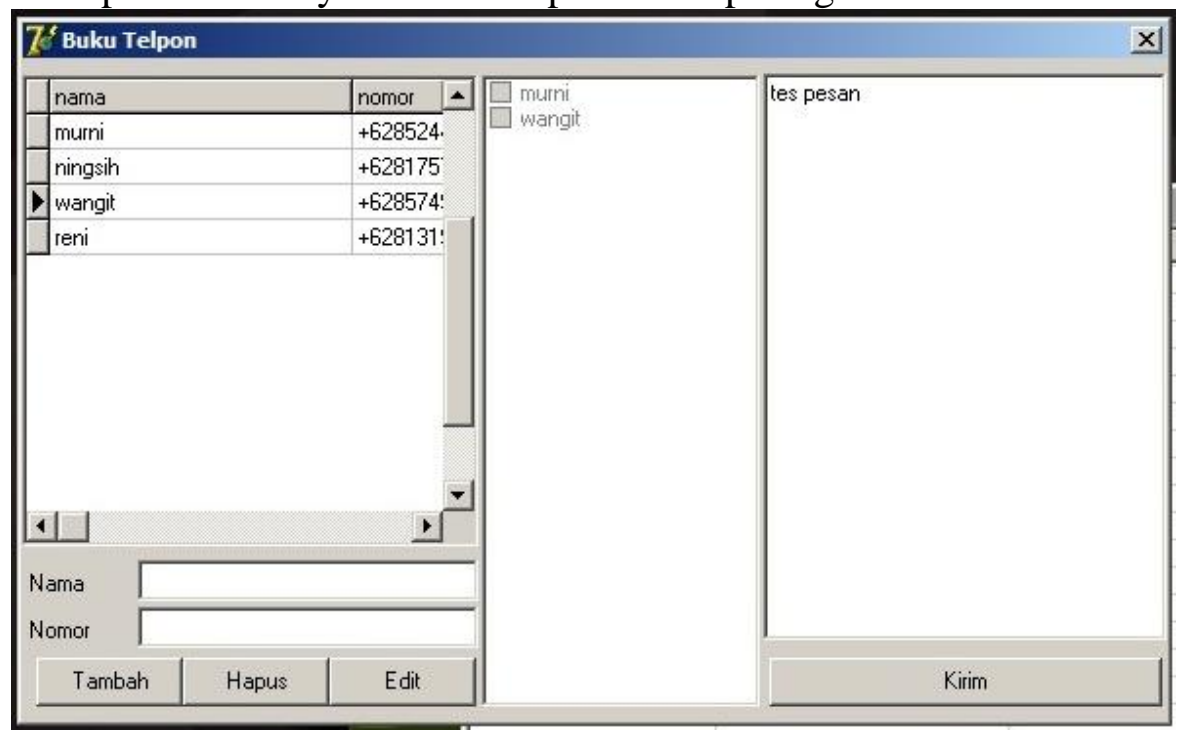

Gambar 12 Pengiriman Pesan ke Banyak Nomor

\section{Uji Operator}

Dalam melakukan uji operator ini menggunakan 5 buah sim card dari 5 operator telepon seluler yang berbeda, yaitu indosat, telkomsel, XL, three, dan axis. Tujuan dari uji operator ini yaitu untuk membandingkan dari setiap sim card yang digunakan untuk mengetahui kecepatan pengiriman pesan dan biaya yang diperlukan untuk mengirim pesan. Hal ini ditunjukkan pada tabel 4 di bawah ini.

Tabel 4 Uji Operator

\begin{tabular}{|c|c|c|c|c|}
\hline No & Nama Operator & $\begin{array}{c}\text { Jumlah Pesan } \\
\text { Keluar }\end{array}$ & Biaya & $\begin{array}{c}\text { Waktu } \\
\text { Pengiriman }\end{array}$ \\
\hline 1 & Indosat M3 & 1 & 125 & 5 detik \\
\hline & Indosat M3 & 2 & 250 & 7 detik \\
\hline 2 & XL & 1 & 150 & 5 detik \\
\hline & XL & 2 & 150 & 6 detik \\
\hline 3 & Telkomsel As & 2 & 99 & 4 detik \\
\hline & Telkomsel As & 1 & 99 & 4 detik \\
\hline 4 & Three & 2 & 99 & 4 detik \\
\hline & Three & 1 & 99 & 6 detik \\
\hline 5 & Axis & 2 & 100 & 5 detik \\
\hline & Axis & 200 & 7 detik \\
\hline
\end{tabular}

Dari tabel uji operator diatas dapat diketahui bahwa biaya dan waktu pengiriman pesan tiap operator berbeda-beda. Untuk pengiriman pesan tercepat menggunakan operator Telkomsel As dan three dengan waktu pengiriman 4 detik per pesan, sedangkan lainnya membutuhkan waktu 5 detik setiap pengiriman pesan. Untuk biaya pengiriman, Telkomsel As dan Three sama-sama membutuhkan 99 rupiah untuk mengirim sebuah pesan, dan XL menjadi operator 
paling mahal karena membutuhkan biaya 150 rupiah untuk mengirimkan sebuah pesan.

\section{Analisa Sistem}

Hasil dari semua percobaan dapat dianalisa dari implementasi dan simulasi percobaan adalah tentang proses mekanisme kerja dari sistem secara keseluruhan. Secara keseluruhan hasil analisa terdiri dari konsep dasar yang dibangun untuk menjadi sebuah sistem dengan apa yang telah dibahas pada bab sebelumnya.

Analisa dari hasil percobaan adalah sebagai berikut:

1. Aplikasi server dan aplikasi client dapat saling berkomunikasi dengan menggunakan port yang telah ditentukan oleh aplikasi server.

2. Pesan yang dikirim oleh pengguna ke komputer client tujuan terlebih dahulu di filter oleh aplikasi server untuk ditentukan ke komputer client yang mana pesan tersebut akan dikirimkan. Dalam uji coba diatas dapat dicontohkan bahwa nama komputer client tujuan yaitu BAAK3, sedangkan isi pesannya yaitu tes pesan.

3. Kecepatan pengiriman pesan dan jumlah biaya yang dikeluarkan untuk mengirim pesan, tergantung dengan kartu telepon seluler yang digunakan.

\section{Kesimpulan}

kesimpulan:

Dari hasil uji coba pada yang dilakukan dapat ditarik beberapa

1. Sistem penyebaran informasi berbasis SMS telah berhasil digunakan untuk mengirim pesan dari komputer ke pengguna dan sebaliknya. Dalam hal ini dapat membantu penyebaran informasi akademik anatara pihak sekolah dan mahasiswa.

2. Jumlah komputer yang digunakan untuk mengirimkan pesan dibatasi oleh alamat jaringan yang sama.

3. Biaya penggunaan SMS dapat dikendalikan karena pengirimannya tercatat pada aplikasi server. Semua SMS yang keluar tercatat dalam database yang ada di server, sehingga jumlah SMS yang keluar dan biaya yang dikeluarkan dapat dihitung.

\section{Saran}

Adapun saran yang diberikan untuk pengembangan tugas akhir ini adalah pengembangan aplikasi selanjutnya diharapkan nama komputer client tidak harus di daftarkan terlebih dahulu di komputer server.

\section{Daftar Pustaka}

Imron Romzi., 2002, Membuat sendiri SMS Gateway (ESME) Berbasis Protokol SMPP, Yogyakarta, Andi Offset

Kadir, Abdul, 2005, Pemrograman Database dengan Delphi Menggunakan Access dan $A D O$, Yogyakarta, Andi Offset

Madcoms, 2003, Pemrograman Borland Delphi 7, Yogyakarta, Andi Offset 
Wangsit Setyaadi, Hero Wintola, Yuliani Indrianingsih

Sutedjo, Budi., 2003, Konsep \& Perancangan Jaringan komputer Bangunan satu lantai, gedung bertingkat \& kawasan Yogyakarta, Andi Offset

Sutedjo, Budi., 2006, Konsep dan Aplikasi Client Server dan Sistem Terdistribusi Yogyakarta, Andi Offset

Syafrizal,Melwin., 2005, Pengantar Jaringan Komputer, Yogyakarta, Andi Offset

Wahana, 2005, Menjadi Administrator Jaringan Komputer, Yogyakarta, Andi Offset 